\title{
0728. Removal of natural anti-galactose $\alpha 1,3$ galactose antibodies with GAS914 enhances humoral immunity and prevents sepsis mortality in mice
}

\author{
R Manez ${ }^{1,2^{*}}$, M Perez-Cruz ${ }^{2}$, D Bello ${ }^{2}$, MA Dominguez ${ }^{3}$, C Costa $^{2}$ \\ From ESICM LIVES 2014 \\ Barcelona, Spain. 27 September - 1 October 2014
}

\section{Introduction}

Increasing numbers of patients with immunodeficiencies, malignant diseases, advanced surgeries and prolonged stays in intensive care units are at risk for developing infections by enteric bacteria, which often are systemic (sepsis) and caused by multidrug resistance isolates. Intestinal bacteria provide also a constant antigenic stimulation for the synthesis of natural anti-carbohydrate antibodies such as those targeting blood group-associated antigens or galactose $\alpha 1,3$ galactose (Gal). Enteric bacteria that cause sepsis are more likely to bind anti-Gal antibodies than those isolated from stools, which appears related to the higher resistance to serum killing evidenced by the former microorganisms.

\section{Objective}

Investigate the impact of removing anti-Gal antibodies in the sepsis after cecal ligation and puncture (CLP) in $\alpha 1,3$ galactosyltransferase knockout (Gal-KO) mice. These mice produce from four months of age natural anti-Gal antibodies as humans without the need of any additional Gal antigen exposure.

\section{Methods}

Anti-Gal antibodies were removed in vivo using a soluble Gal trisaccharide-polylysine conjugate (GAS914) and determined by ELISA. Binding of serum antibodies to Escherichia Coli isolated from Gal-KO mice blood was performed by FACS and serum bactericidal activity was determined by a complement-mediated assay. The

${ }^{1}$ Hospital Universitari de Bellvitge, Intensive Care Medicine, Hospitalet de Llobregat, Spain

Full list of author information is available at the end of the article pattern of 40 cytokines and antibodies against 577 carbohydrate and bacterial antigens before and after GAS914 was evaluated by two different arrays.

\section{Results}

GAS914 at $10 \mathrm{mg} / \mathrm{kg}$ subcutaneously every other day for two weeks led to the removal of anti-Gal antibodies in Gal-KO mice from day one. Removal of anti-Gal antibodies with GAS914 significantly improved survival in GalKO mice subsequently subjected to CLP on day 3 ( $83 \%$ versus $35 \%$ in controls; $p<0.01$ ). On day one after CLP there was a reduction of $50 \%$ in the level of anti-Gal antibodies in untreated Gal-KO mice. Blood cultures obtained $24 \mathrm{~h}$ after CLP were positive for Escherichia Coli in $83 \%$ of mice carrying anti-Gal antibodies and $87.5 \%$ of the animals lacking them. Pulse field electrophoresis did not show differences between $E$. Coli blood isolates from GAS914-treated and untreated mice. Removal of anti-Gal antibodies was associated with a significant increase in serum IgG binding and bactericidal activity to E. Coli. GAS914 administration was associated in the glycan array with the removal of anti-Gal antibodies and the significant augment of binding to several bacterial antigens. Finally, GAS914 also significantly reduced the level of several proinflammatory and antiinflammatory cytokines prior to CLP in Gal-KO mice.

\section{Conclusion}

Removal of natural anti-Gal antibodies with GAS914 enhances humoral immunity against enteric bacteria expressing Gal-antigen isolated from the blood preventing sepsis mortality after CLP in mice. Depletion of existing antibodies may be a new approach to boost

\section{SpringerOpen ${ }^{\circ}$}

(C) 2014 Manez et al; licensee Springer. This is an Open Access article distributed under the terms of the Creative Commons Attribution License (http://creativecommons.org/licenses/by/2.0), which permits unrestricted use, distribution, and reproduction in any medium, provided the original work is properly cited. 
immunity and prevent or treat infection diseases and other disorders.

\section{Authors' details}

'Hospital Universitari de Bellvitge, Intensive Care Medicine, Hospitalet de Llobregat, Spain. ${ }^{2}$ Idibell, Hospital Universitari de Bellvitge, Hospitalet de Llobregat, Spain. ${ }^{3}$ Hospital Universitari de Bellvitge, Hospitalet de Llobregat, Spain.

Published: 26 September 2014

doi:10.1186/2197-425X-2-S1-P50

Cite this article as: Manez et al.: 0728. Removal of natural anti-galactose $\alpha 1,3$ galactose antibodies with GAS914 enhances humoral immunity and prevents sepsis mortality in mice. Intensive Care Medicine Experimental 2014 2(Suppl 1):P50.

\section{Submit your manuscript to a SpringerOpen ${ }^{\mathcal{O}}$ journal and benefit from:}

- Convenient online submission

- Rigorous peer review

- Immediate publication on acceptance

- Open access: articles freely available online

- High visibility within the field

- Retaining the copyright to your article

Submit your next manuscript at $\gg$ springeropen.com 